\title{
Secondary Metabolites Screening and Acute Toxicity Test of Peperomia pellucida(L.) Kunth Methanolic Extracts
}

\author{
Desy Rasta Waty ${ }^{1 *}$, Fadlina Chany Saputri ${ }^{2}$, Abdul Mun'im $^{3}$ \\ ${ }^{1}$ Graduate Program of Herbal Medicine, Faculty of Pharmacy, Universitas Indonesia, \\ Depok, West Java, Indonesia \\ ${ }^{2}$ Laboratory of Pharmacology-Toxicology, Faculty of Pharmacy, Universitas Indonesia, \\ Depok, West Java, Indonesia \\ ${ }^{3}$ Laboratory of Pharmacognosy, Faculty of Pharmacy, Universitas Indonesia, Depok, \\ West Java, Indonesia
}

\begin{abstract}
Peperomia pellucida (L.) Kunth. is a wild plant that can be found in various shaded and damp habitats in tropical and subtropical climate. Aerial part of this plant is traditionally used as a medicine in Indonesia such as dizziness, headache, fever, and stomach ache. This study aims to determine the content of secondary metabolites and acute toxicity of methanolic extracts of Peperomia pellucida (L.) Kunth herb. The methanolic extract obtained by gradual maceration using n-hexane and methanol. Secondary metabolites analysis by appropriate reagents showed that methanol extract contains flavonoids, tannins, and steroids. Acute toxicity tests performed in DDY mice showed that methanol extract $\mathrm{LD}_{50}$ is greater than $4000 \mathrm{mg} / \mathrm{kgBW}$. There was no sign of toxicity on the skin and hair, respiration system, defecation, feed intake and behavior up to $4000 \mathrm{mg} / \mathrm{kgBW}$. At that dose, the extract did not cause mortality, influence growth, and liver damage.
\end{abstract}

Keywords : Peperomia pellucida (L.) Kunth, acute toxicity, methanol extract, $\mathrm{LD}_{50}$.

\section{Introduction}

Peperomia pellucida(L.)Kunth is a wild plant from tropical America that has been widely grown in many countries. This herb grows in shaded and damp hard surfaces, such as walls, rock, steep gullies, and in flower potsas a weed ${ }^{1}$. Many countries in tropical America used this plant as medicine, such as to stop hemorrhages (Bolivia), hypercholesteremic agent (northeastern Brazil), cough suppressant (Guyana), treatment proteinuria (Amazon). In Asian countries, this plantalso used as traditional medicine. In Philippine, this plant is used to treat acne, renal problem, and decreasing uric acid levels ${ }^{2}$. In India, the whole plant is used to treat a cough, the renal problem (kidney disorder, dysuria, urinary retention,urinary tract infections), and general weakness ${ }^{3}$.In Indonesia, the crumpled leaves are used to treat dizziness or headaches if the patient has a fever ${ }^{1}$. 
Peperomia pellucida(L.)Kunth from many studies have been known to have secondary metabolite i.e. alkaloid, saponin and tannin ${ }^{2}$, secolignans, tetrahydrofuran lignans, and methoxylated dihydronaphthalenone ${ }^{4}$, $x^{x}$ thon $^{5}$, flavon, steroid and terpenoid ${ }^{6}$.Pharmacological study of Peperomia pellucida $($ L.)Kunth showed that this plant has antidiabetic activity, antioxidant ${ }^{7}$, antibacterial ${ }^{8}$, analgesic ${ }^{9,10}$, antiinflammation ${ }^{10}$ and antihypertension $^{11,12}$.

Toxicity study of ethanolic extract showed that Peperomia pellucida(L.) Kunth has $\mathrm{LD}_{50} 15.13 \mathrm{~g} / \mathrm{kg}$ $\mathrm{BW}$ male miceand11.87 g/kg BW female mice; meanwhile, $\mathrm{LD}_{50}$ for aqueous extract is more than $5000 \mathrm{mg} / \mathrm{kg}$ $\mathrm{BW}^{13}$. Peperomia pellucida aqueous extract categorized as low toxicity $(>5000 \mathrm{mg} / \mathrm{kg} \mathrm{BW})^{10}$.

This study aims to investigate phytochemical and acute toxicity $\left(\mathrm{LD}_{50}\right)$ of Peperomia pellucida $(\mathrm{L}$. Kunth methanolic extract.

\section{Experimental}

\section{Plant materials}

Peperomia pellucida(L.)Kunth was collected from Bogor, West Java, Indonesia. The species was identified and determination by Plant Conservation Botanic GardensCenter, Indonesian Institute of Sciences, Bogor.The voucher specimen was deposited in Herbarium of Pharmacognosy-Phytochemistry Laboratory, Faculty of Pharmacy, Universitas Indonesia. The plant was dried in open air then in the drying cabinet. Dry sortation the plant to separate unwanted material such as other plants, rocks, soils, and other impurities.Powdered the dried plant then keep in sealed bag.

\section{Extract preparation}

Peperomia pellucida(L.)Kunth.powder was extracted by gradual maceration process with n-hexane, continued with methanol ( $6 \times 24$ hours each). Liquid extract was then concentrated with rotary vacuum evaporator at $40^{\circ} \mathrm{C}$, and then was dried with vacuum the oven at $40^{\circ} \mathrm{C}$. The final extract put in the sealed bottle and stored in a refrigerator for further analysis.

\section{Phytochemical screening}

Secondary metabolite presence analysis is done by phytochemical screening. The Peperomia pellucida methanolic extract was qualitatively tested for the phytochemical screening using standard established method. Secondary metabolite tested for flavonoid, alkaloid, saponin, tannin, quinon, steroid, and triterpenoid.

\section{Animals}

The DDY mice male and female were purchased from Animal Production and Technology Department, Faculty of Animal Science, Bogor Agricultural University.The animals weighed 20-40 g, housed five mice per cage and maintained at a constant 12-hour light/12-hour dark cycle. Feed and water were available ad libitum. The animals were examined and weighed and kept in their cages for 7 days prior to the first day of study then allowed to for acclimatization to the laboratory environment. Ethical approval for the protocol testing was received from Health Research Ethics Committee - Universitas Indonesia and Cipto Mangunkusumo Hospital.

\section{Doses}

The acute toxicity of methanol extract was studied by preparing four different doses, i.e. 500, 1000, 2000 and $4000 \mathrm{mg} / \mathrm{kg}$ body weight. Before administered the test dose orally, animals fasted (only feed not water for 3-4 hours). Following the period of fasting, the animals weighed and then administered the extract. The feed may be withheld after 1-2 hours of extract administration.

\section{Toxicity symptoms observation}

Observations of the animals were done individually after extractadministered for the first 30 minutes, periodically during the first 24 hours and special attention given during the first 4 hours, and daily thereafter, for a total of 14 days. Toxicity symptoms observation include changes in skin and fur, eyes, respiratory, salivation, diarrhea, urination, and the central nerve effects including tremors, and behavior pattern. 


\section{Body weight and feed consumption}

Individual body weight was measured and recorded prior to the administration of extracts for 14 days. Weight changes were also calculated and recorded. The amount of feed consumption was measured daily from the food quantity remaining after 24 hours for 14 days of the study period.

\section{Organ weight and histopathology}

Animal organs were collected at the end of the acute toxicity study (14 days) using standardized surgical procedures. Each abdominal cavity of the animal was dissected for their organs namely the heart, liver, and kidney. Then, they were quickly removed, cleaned with saline, weighed and preserved in $10 \%$ formalin for histopathology analysis. Macroscopic examination from heart, liver and kidney is done by observing the color, size and morphological abnormalities of organ. Histopathology slides of the liver, heart and kidney prepared using hematoxylin and eosin staining (HE).

\section{Blood Biochemical}

Blood serums were collected at the end of the toxicity study (14 days). Animals were anesthetized and then dissected for collecting blood from heart aorta valve. Collected blood centrifuged $3500 \mathrm{rpm}$ for 15 minutes to have clear serum. Serum stored at $\sim-20^{\circ} \mathrm{C}$ for further analysis. In this study, the liver function test is done by analyzing Alanine aminotransferase (ALT) and aspartate aminotransferase (AST)from serum.

\section{Statistical analysis}

The results are expressed as the mean \pm SD for each group. Statistical differences were evaluated using one-way analysis of variance (ANOVA) followed by Post hoc Test. The results were statistically significant at $\mathrm{p}>0.05$.

\section{Result}

\section{Phytochemical Screening}

Phytochemical screening showed that Peperomia pellucida(L.) Kunth methanol extract contains flavonoid, tannin, and steroid. Alkaloid, saponin, quinon and triterpenoid observed to be absent.

\section{Acute toxicity study}

\section{Mortality and toxicity symptoms observation}

There was no mortality of animal until the end of the study in all group (14 days). Observation of the toxicity symptoms between normal and doses group showed no differences in behavior, skin effect, loss of hair, breathing, defecation, and impairment in feed intake consumption.

\section{Body weight and feed consumption}

Body weight of each animal was recorded every day for 14 days. An increased body weight significantly is shown in male mice, while in female mice not occur $(>0,05)$.

Feed consumption of all groups has a significant correlation with the body weight. As we can see in the Table 1,that normal female mice group has the highest feed consumption but not correlated to body weight gain significantly.

Table 1 Body weight (g) and food consumption (g/mice)

\begin{tabular}{|c|c|c|c|c|c|c|c|c|c|c|}
\hline & \multicolumn{2}{|c|}{ Normal } & \multicolumn{2}{|c|}{$500 \mathrm{mg} / \mathrm{kg} \mathrm{BW}$} & \multicolumn{2}{|c|}{$1000 \mathrm{mg} / \mathrm{kg} \mathrm{BW}$} & \multicolumn{2}{|c|}{$2000 \mathrm{mg} / \mathrm{kg}$ BW } & \multicolumn{2}{|c|}{$4000 \mathrm{mg} / \mathrm{kg} \mathrm{BW}$} \\
\hline & BW & Food & BW & Food & BW & Food & BW & Food & BW & Food \\
\hline Male & $\begin{array}{r}38.75 \\
+3.46\end{array}$ & $\begin{array}{r}8.22 \\
+1.07\end{array}$ & $\begin{array}{r}33.72 \\
+3.19\end{array}$ & $\begin{array}{c}7.11 \\
+1.05\end{array}$ & $\begin{array}{r}35.18 \\
+5.02\end{array}$ & $\begin{array}{r}8.58 \\
+1.25\end{array}$ & $\begin{array}{r}35.40 \\
+6.50\end{array}$ & $\begin{array}{c}6.53 \\
+1.28\end{array}$ & $\begin{array}{r}36.20 \\
+4.77\end{array}$ & $\begin{array}{c}7.89 \pm \\
1.01\end{array}$ \\
\hline Female & $\begin{array}{r}27.93 \\
+2.08\end{array}$ & $\begin{array}{c}9.0 \\
+0.84\end{array}$ & $\begin{array}{r}25.60 \\
+5.72\end{array}$ & $\begin{array}{c}5.58 \pm \\
1.51\end{array}$ & $\begin{array}{r}27.89 \\
+2.36\end{array}$ & $\begin{array}{l}6.417 \\
+1.79\end{array}$ & $\begin{array}{r}29.40 \\
+1.89 \\
\end{array}$ & $\begin{array}{c}5.24 \\
+1.14\end{array}$ & $\begin{array}{r}28.96 \\
+3.90\end{array}$ & $\begin{array}{c}7.18 \pm \\
1.49\end{array}$ \\
\hline
\end{tabular}




\section{Organ weight}

At the end of experiment for acute toxicity test period (14 days), organ weights of mice were measured. Absolute organ weight on all groups showed no significant differences (Table 2 and Table 3). Relative organ weight is a comparison of absolute organ weight to the body weight. There are also no significant differences in relative organ weight for all groups ( $>0.05)$. Macroscopic observation of liver, heart and kidney showed no difference between normal groups and dose groups.

Table 2 Male absolute and relative organ weight

\begin{tabular}{|l|c|c|c|c|c|}
\hline Organ & Normal & $\mathbf{5 0 0} \mathbf{~ m g / k g ~ B W}$ & $\mathbf{1 0 0 0} \mathbf{~ m g} / \mathbf{k g ~ B W}$ & $\mathbf{2 0 0 0} \mathbf{~ m g} / \mathbf{k g} \mathbf{B W}$ & $\mathbf{4 0 0 0} \mathbf{~ m g} / \mathbf{k g ~ B W}$ \\
\hline Liver & $2.28 \pm 0.27$ & $2.01 \pm 0.201$ & $2.07 \pm 0.591$ & $1.97 \pm 0,501$ & $2.20 \pm 0.277$ \\
\hline RW & $5.67 \pm 0.16$ & $5.96 \pm 0.38$ & $5.67 \pm 0.80$ & $5.62 \pm 0.61$ & $5.89 \pm 0.58$ \\
\hline Kidney & $0.73 \pm 0.075$ & $0.48 \pm 0.132$ & $0.66 \pm 0.167$ & $0.498 \pm 0.136$ & $0.576 \pm 0.121$ \\
\hline RW & $1.82 \pm 0.22$ & $1.4 \pm 0.2$ & $1.82 \pm 0.22$ & $1.42 \pm 0.15$ & $1.52 \pm 0.13$ \\
\hline Heart & $0.26 \pm 0.095$ & $0.184 \pm 0.03$ & $0.134 \pm 0.05$ & $0.194 \pm 0.06$ & $0.23 \pm 0.065$ \\
\hline RW & $0.66 \pm 0.27$ & $0.54 \pm 0.05$ & $0.37 \pm 0.10$ & $0.55 \pm 0.11$ & $0.60 \pm 0.122$ \\
\hline
\end{tabular}

$\mathrm{RW}=$ Relative weight $(\%)$

Table 3 Female absolute and relative organ weight

\begin{tabular}{|l|l|l|l|l|l|}
\hline Organ & Normal & $\mathbf{5 0 0} \mathbf{~ m g} / \mathbf{k g ~ B W}$ & $\mathbf{1 0 0 0} \mathbf{~ m g} / \mathbf{k g ~ B W}$ & $\mathbf{2 0 0 0} \mathbf{~} \mathbf{~ B} / \mathbf{k g ~ B W}$ & $\mathbf{4 0 0 0} \mathbf{~ m g} / \mathbf{k g ~ B W}$ \\
\hline Liver & $1.88 \pm 0.22$ & $1.56 \pm 0.36$ & $1.72 \pm 0.30$ & $1.76 \pm 0.36$ & $1.84 \pm 0.15$ \\
\hline RW & $5.99 \pm 0.76$ & $6.12 \pm 0.87$ & $6.20 \pm 1.32$ & $5.86 \pm 1.09$ & $6.25 \pm 0.86$ \\
\hline Kidney & $0.37 \pm 0.11$ & $0.46 \pm 0.21$ & $0.41 \pm 0.10$ & $0.45 \pm 0.07$ & $0.45 \pm 0.14$ \\
\hline RW & $1.18 \pm 0.35$ & $1.82 \pm 0.79$ & $1.46 \pm 0.40$ & $1.56 \pm 0.27$ & $1.47 \pm 0.36$ \\
\hline Heart & $0.22 \pm 0.03$ & $0.13 \pm 0.06$ & $0.13 \pm 0.05$ & $0.23 \pm 0.07$ & $0.18 \pm 0.05$ \\
\hline RW & $0.70 \pm 0.11$ & $0.55 \pm 0.32$ & $0.45 \pm 0.18$ & $0.78 \pm 0.24$ & $0.62 \pm 0.21$ \\
\hline
\end{tabular}

RW = Relative weight (\%)

\section{Histopathology}

Histopathological observation showed no specific abnormalities in heart, liver and kidney between normal groups and dose groups. Color difference in organ slide due to the ability of the tissue to stained (Figure 1,2 , and 3).

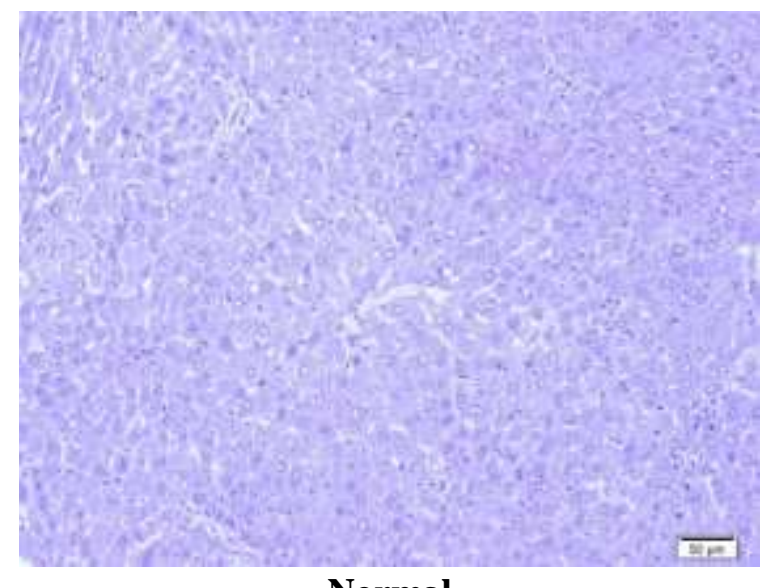

Normal 


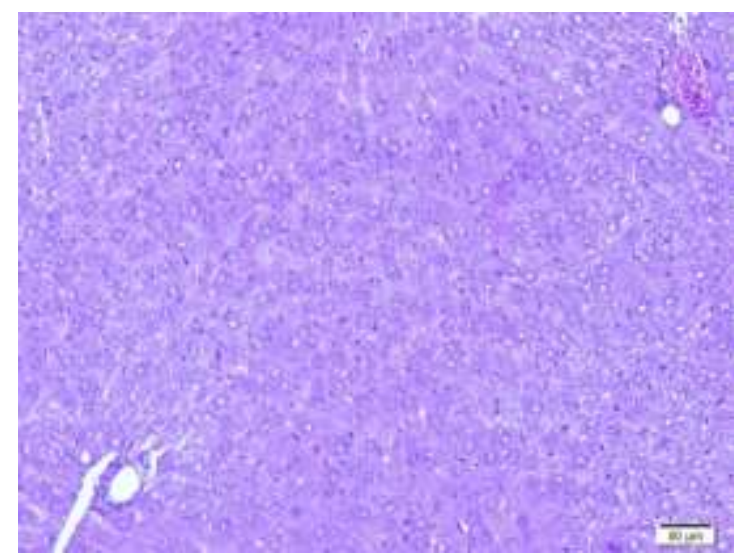

$500 \mathrm{mg} / \mathrm{kg} \mathrm{BW}$

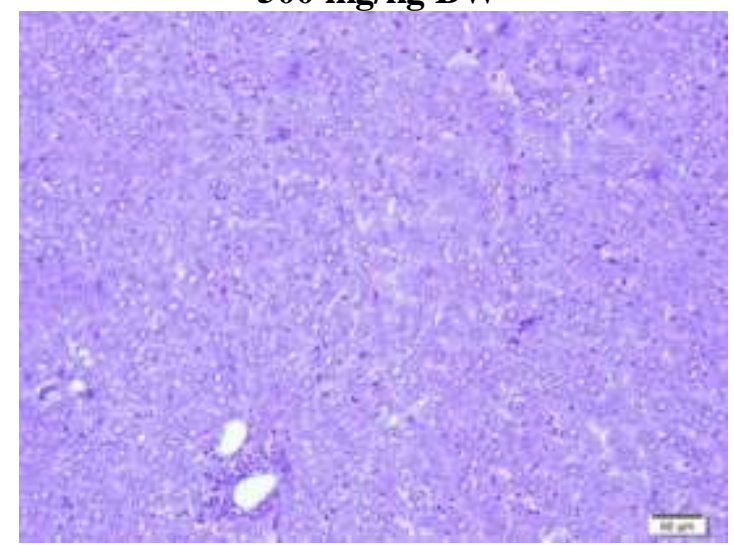

$2000 \mathrm{mg} / \mathrm{kg} \mathrm{BW}$

Figure 1. Liver tissue (HE stained,200x)

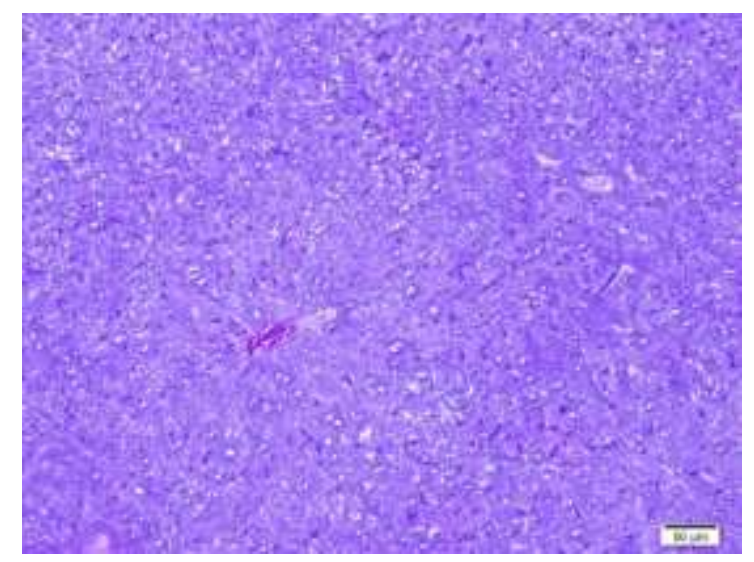

$1000 \mathrm{mg} / \mathrm{kg} \mathrm{BW}$

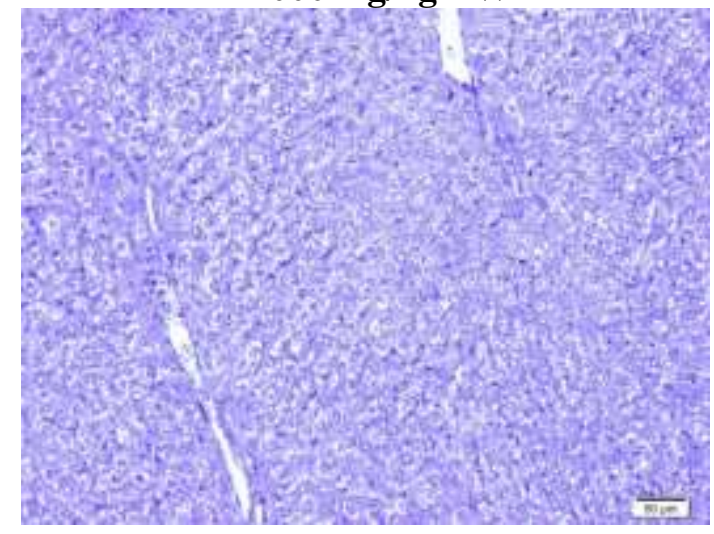

$4000 \mathrm{mg} / \mathrm{kg}$ BW

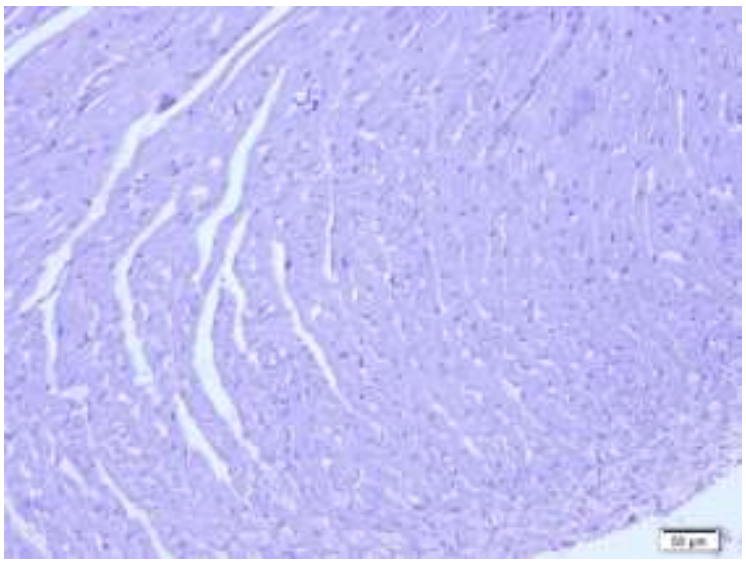

Normal

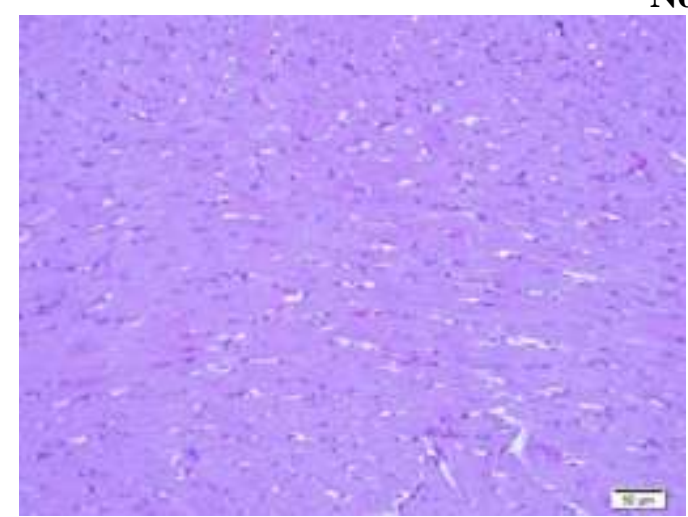

$500 \mathrm{mg} / \mathrm{kg} \mathrm{BW}$

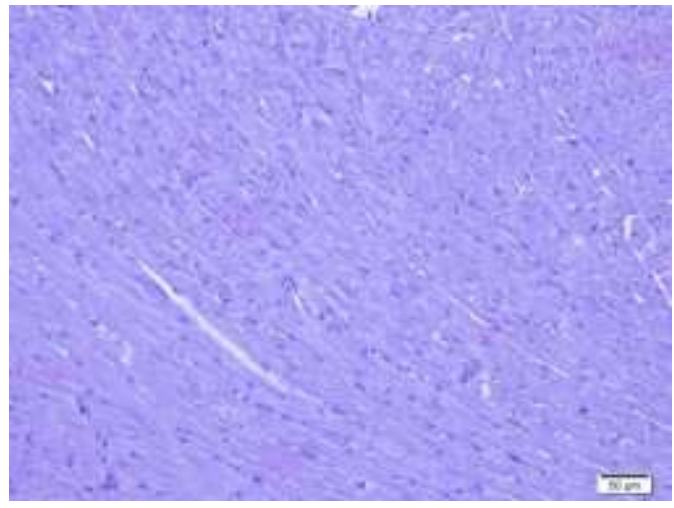

$1000 \mathrm{mg} / \mathrm{kg} \mathrm{BW}$ 


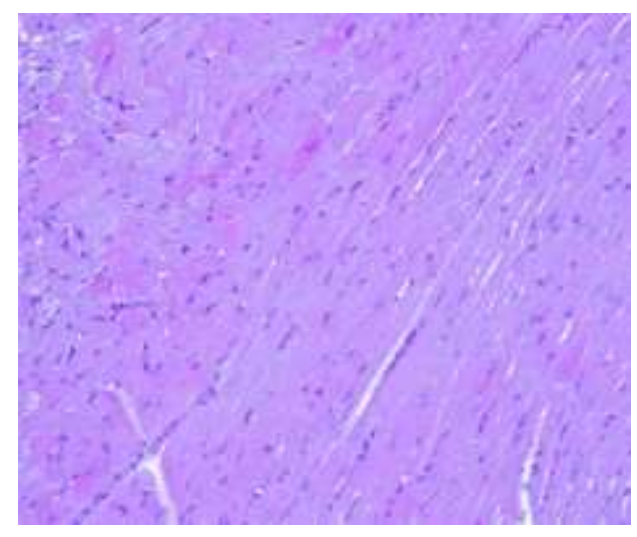

$2000 \mathrm{mg} / \mathrm{kg} \mathrm{BW}$

Figure 2. Heart Tissue (HE stained,200x)

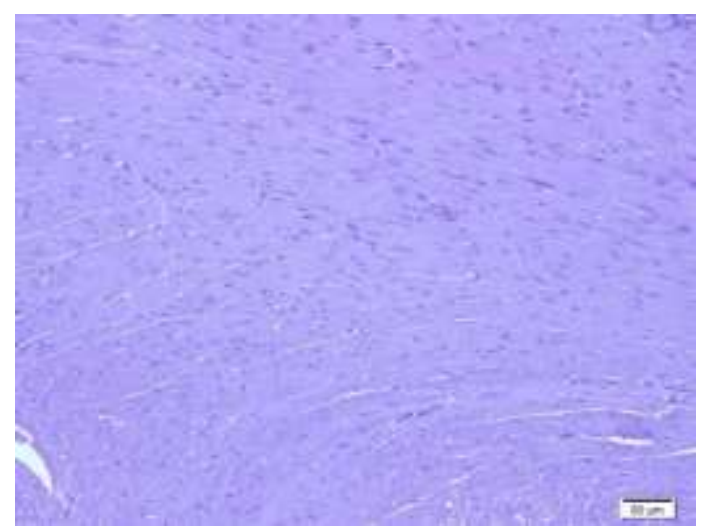

$4000 \mathrm{mg} / \mathrm{kg} \mathrm{BW}$

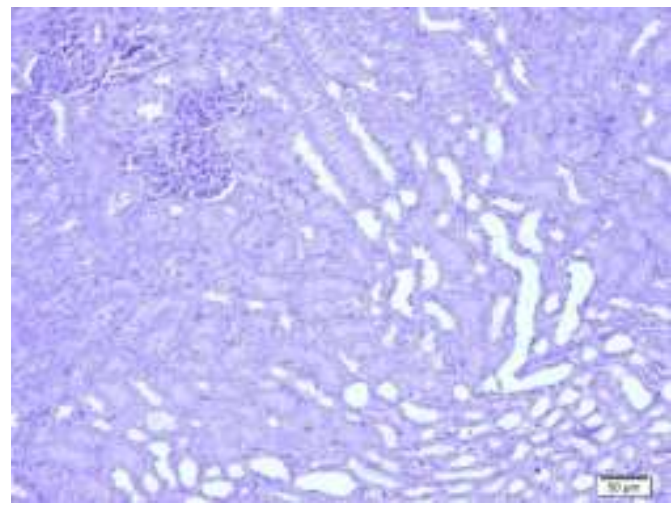

Normal

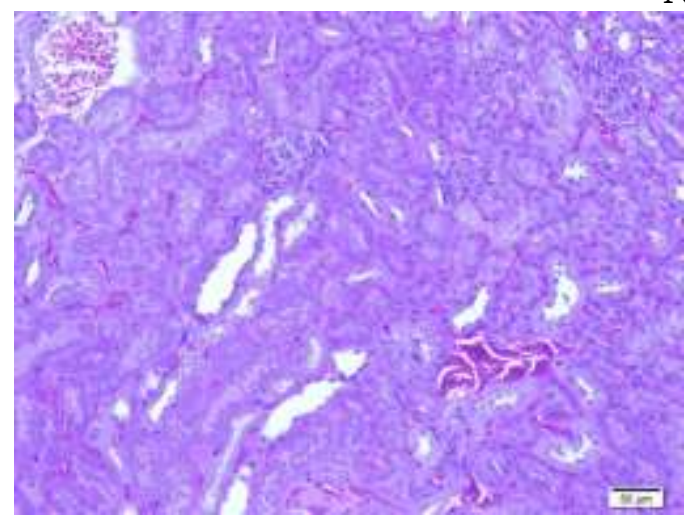

$500 \mathrm{mg} / \mathrm{kg} \mathrm{BW}$

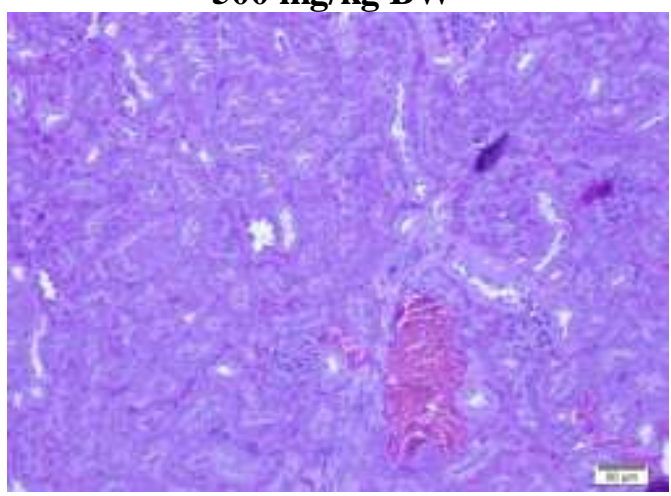

$2000 \mathrm{mg} / \mathrm{kg} \mathrm{BW}$

Figure 3. Kidney tissue (HE stained,200x)

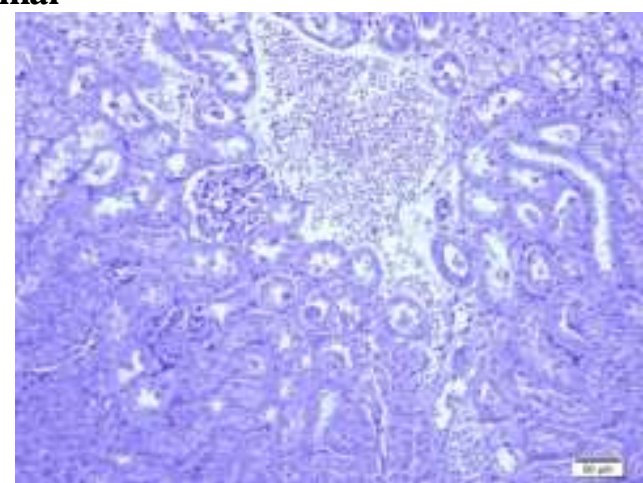

$1000 \mathrm{mg} / \mathrm{kg} \mathrm{BW}$

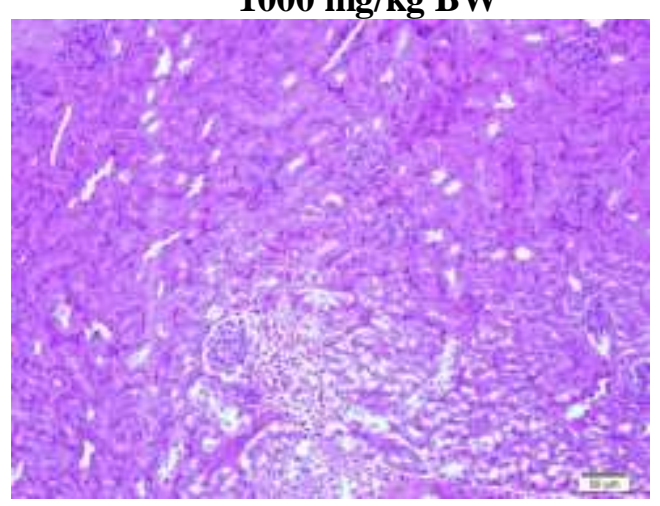

$4000 \mathrm{mg} / \mathrm{kg} \mathrm{BW}$ 


\section{Blood biochemical}

ALT level for all normal groups showed no significant difference between all groups. Male groups $1000 \mathrm{mg} / \mathrm{kg}$ BW showed significant differences ALT level with $2000 \mathrm{mg} / \mathrm{kg} \mathrm{BW}$ and $4000 \mathrm{mg} / \mathrm{kg} \mathrm{BW}$ group, and for AST level showed significant differences with all groups. ALT and AST level for all female groups showed no significant differences (0.05). The result of AST and ALT level as showed in Table 4.

Table 4 AST and ALT level

\begin{tabular}{|l|l|l|l|l|l|l|}
\hline & & \multicolumn{1}{|c|}{ Normal } & $\mathbf{5 0 0} \mathbf{~ m g} / \mathbf{k g}$ BW & $\mathbf{1 0 0 0} \mathbf{~ m g} / \mathbf{k g}$ BW & $\mathbf{2 0 0 0} \mathbf{~ m g} / \mathbf{k g}$ BW & $\mathbf{4 0 0 0} \mathbf{~ m g} / \mathbf{k g}$ BW \\
\hline AST & Male & $58.70+8.46$ & $62.85+14.41$ & $36.14+22.34$ & $66.76+13.12$ & $67.68+3.08$ \\
\hline & Female & $34.30+5.42$ & $24.86+13.413$ & $23.48+15.06$ & $38.90+9.91$ & $37.35+3.39$ \\
\hline ALT & Male & $26.24+11.88$ & $26.70+18.40$ & $7.37+8.36$ & $44.66+7.52$ & $43.28+21.19$ \\
\hline & Female & $29.01+15.28$ & $24.86+15.49$ & $19.11+11.55$ & $20.72+2.57$ & $35.68+13.34$ \\
\hline
\end{tabular}

\section{Discussion}

Peperomia pellucida is a native plant of South America but has been widely used as a traditional medicine in some countries. Many studies regarding to the pharmacological activities of this plant, but a leak of data on toxicity and adverse effect. Toxicity study is important to have safety guarantee for the use of natural material for human health.

Our study of Peperomia pellucida methanol extract showed the presence of flavonoid, tannin and steroid. In the previous study, we have isolated quercetin (flavonoid) that have ACE inhibitor (antihypertension) activity from methanol extract ${ }^{12}$. Raman (2012) study on phytochemical screening on methanol extract exhibit the presence of flavonoid, saponin and alkaloid in sequential maceration with dichloromethane, ethyl acetate and methanol ${ }^{14}$.The presence of secondary metabolites will most likely differ influenced by environment conditions ${ }^{15}$.A secondary metabolite is the characteristic feature of plants against a wide variety of microorganisms (viruses, fungi, bacteria) and herbivores (vertebrates,arthropods). Plant biological activities might be related to human biological activities. Flavonoid in the plant can become antibacterial, this function in plant showed correlation with Peperomia pellucida activity as antimicrobial activity ${ }^{8,14,15}$. Secondary metabolite function in the plant can be the basis of the biological activity ${ }^{15}$. The use of different solvent will produce different secondary metabolites. Polarity level of the solvent affect the withdrawal of a secondary metabolites in plants $^{14}$.

Observation of toxicity test for 14 days of Peperomia pellucida methanol extract dose 500, 1000, 2000, and $4000 \mathrm{mg} / \mathrm{kg}$ BWshowed no mortality and no symptoms of toxicity. Therefore, the $\mathrm{LD}_{50}$ value is greater than $4000 \mathrm{mg} / \mathrm{kg} \mathrm{BW}^{16}$. OECD guideline mentions that the highest dose level for acute toxicity is $5000 \mathrm{mg} / \mathrm{kg} \mathrm{BW}$, for reason of animal welfare concern ${ }^{17}$.

Acute toxicity test observation on bodyweight parameter showed no significant weight gain in female while male group showed significant weight gain. Feed consumption for all group has a significant correlation with the body weight. This result showed that Peperomia pellucida extract did not influence food appetite and growth. Organ weight analysis showed that there were no significant changes in the absolute and relative organ weight of the liver, heart, and kidney in all group. Body weight changes, feed intake and organ weight result showed no significant differences, it is suggested that oral administration of Peperomia pellucida extract did not influence normal growth and metabolism ${ }^{18}$.

Blood collecting from heart aorta valve is to obtain an optimum blood sample. ALT and AST level were parameters for reviewing liver function. ALT level of male group dose $1000 \mathrm{mg} / \mathrm{kg} \mathrm{BW}$ showed the lowest level. For male normal group showed no significant difference with other groups. The liver disorder can be seen when ALT and AST level is increasing. ALT is an enzyme which can be found only in the cytoplasm, while AST in mitochondria and cytoplasm. ALT level can be used to determine liver and heart damage. AST values on chronic hepatotoxic conditions can be increased 5 to 10 times the normal value ${ }^{19}$. ALT and AST level of single administered Peperomia pellucida extract showed no differences between normal group and dose groups. This results showed that there is no liver damage and heart damage of oral administered Peperomia pellucida extract dose less than $4000 \mathrm{mg} / \mathrm{kg} \mathrm{BW}$. 
Histopathology as a microscopic analysis for tissue organ support blood chemistry analysis. From histopathology Figure 1 and 2, showed that no differences between normal groups and dose groups in liver and heart tissue. Color difference in organ slide due to the ability of the tissue to stained ${ }^{16}$.

Based on blood and tissue data, we can conclude that Peperomia pellucida extract does not cause damage to liver and heart at doses less than $4000 \mathrm{mg} / \mathrm{kg} \mathrm{BW}$. Further study needed to determine the compounds contained in Peperomia pellucida extract and further analysis for blood biochemistry parameters.

\section{References:}

1. K. Heyne, Tumbuhan Berguna Indonesia, Jilid 2. Penerbit Yayasan Sarana Wana Jaya; 1988.

2. $\quad$ R.U. Egwuche, A.A. Odetola and O.L. Erukainure, Res. J. Phytochem., 5, 48 (2011); doi:10.3923/riphyto.2011.48.53.

3. P. Majumder, J. Pharmaceut. Scientific Innov., 1, 7 (2012).

4. S. Xu, N. Li, M.-M. Ning, C.-H. Zhou, Q.-R. Yang and M.-W. Wang, J. Nat. Prod., 69, 247 (2006); doi:10.1021/np050457s.

5. A. Khan, M. Rahman and S. Islam, Isolation and Bioactivity of a Xanthone Glycoside from Peperomia pellucida, Life Sciences and Medicine Research, pp. 1-10 (2010).

6. P. Majumder, P. Abraham and V. Satya, Res. J. Pharm. Biol. Chem. Sci., 2, 358 (2011).

7. R.U. Hamzah, A.A. Odetola, O.L. Erukainure and A.A. Oyagbemi, J. Acute Dis., 1, 135 (2012); doi:10.1016/S2221-6189(13)60031-1.

8. M.R. Khan and A.D. Omoloso, Fitoterapia, 73, 251 (2002); doi:10.1016/S0367-326X(02)00066-7.

9. P.I. Aziba, A. Adedeji, M. Ekor and O. Adeyemi, Fitoterapia, 72, 57 (2001); doi:10.1016/S0367326X(00)00249-5.

10. M. de Fátima Arrigoni-Blank, E.G. Dmitrieva, E.M. Franzotti, A.R. Antoniolli, M.R. Andrade and M. Marchioro, J. Ethnopharmacol., 91, 215 (2004); doi:10.1016/j.jep.2003.12.030.

11. F.C. Saputri, Int. J. Pharmaceut. Sci. Res., 6, 1054 (2015).

12. A. Kurniawan, F.C. Saputri, I. Ahmad and A. Mun, Int. J. Pharm. Tech. Res., 9, 115 (2016).

13. I.D. Dewijanti, M. Angelina, S. Hartati, B.E. Dewi and L. Meilawati, J. Ilmu Kefarmasian Indonesisa, 12, 255 (2014).

14. Nirosa R. Isolation of chemical compound from Methanol extract of Peperomia pellucida, Fak Sains dan Teknol Univ Malaysia Trengg., (2012)

15. M. Wink, Theor. Appl. Genet., 75, 225 (1988); doi:10.1007/BF00303957.

16. T.B. Ernawati, Int. J. Pharm. Tech. Res., 8, 642 (2015).

17. OECD. OECD Guideline for Testing of Chemicals, Guideline 423: Acute Oral Toxicity - Acute Toxic Class Method., pp. 1-14 (2001).

18. S.N. Harizal, S.M. Mansor, J. Hasnan, J.K.J. Tharakan and J. Abdullah, J. Ethnopharmacol., 131, 404 (2010); doi:10.1016/j.jep.2010.07.013.

19. S. Hasti, H. Muchtar and A. Bakhtia, J. Penelit Farm Indonesia, 1, 34 (2012). 